\title{
Screen Dependency Disorders (SDD): An Innovative Contest for Brain of Children
}

\author{
Sachin Kumar Sharma* and Mihir Y Parmar \\ Parul Institute of Pharmacy and Research, Parul University, Vadodara, Gujarat, India
}

Submission: June 14, 2018; Published: June 27, 2018

*Corresponding author: Sachin Kumar Sharma, Parul Institute of Pharmacy and Research, Parul University, India, Tel: +91-9929873379;

Email: sachin.sharma19126@paruluniversity.ac.in, sachinbest20@gmail.com

\begin{abstract}
Neurological development of children is predisposed by their know-hows. Early involvements and the environments in which they occur can alter gene expression and affect long-term neural development. Presently, open screen time, often involving multiple devices, is the single main experience and environment of children. Various screen activities are reported to induce structural and functional brain malleability in adults. However, childhood is a time of significantly greater changes in brain anatomical structure and connectivity. Pragmatic evidence suggest that extensive exposure to videogame playing during childhood may lead to neuroadaptation and structural changes in neural regions connected with addiction. Digital natives exhibit a higher frequency of screen-related 'addictive' behavior that reflects impaired neurological reward processing and impulse-control mechanisms. This review article explains the basis of current pediatric neurological concerns surrounding SDS and put forward preventive strategies for child neurology and allied professions.
\end{abstract}

Keywords: Brain; Children; Screen Dependency Disorders

\section{Introduction}

Screen viewing now begins in infancy with new research finding that the predominance of screen viewing in children aged under two years 'is high and looks to surge steadily across age groups' [1]. Associations are emerging between screen dependency disorders such as Internet Addiction Disorder and specific neurogenetic polymorphisms; abnormal neural tissue and neural function. Although unusual neural structural and functional characteristics may be a precondition rather than a magnitude of addiction; there may also be a bidirectional relationship. As is the case with substance addictions; it is possible that intensive routine exposure to certain screen activities during grave stages of neural development may alter gene expression resulting in structural; synaptic and functional changes in the developing brain leading to SDS; particularly in children with predisposing neurogenetic profiles [1]. There may also be compound/secondary effects on neural development. Screen dependency disorders; even at subclinical levels; involve high levels of unrestricted screen time; inducing greater child deskbound behavior thereby reducing vital aerobic fitness; which plays an important role in the neurological health of children; particularly in brain structure and function. Child health policy must therefore adhere to the principle of precaution as a prudent approach to protecting child neurological integrity and well-being [2]. 'Addiction' is a term increasingly used to describe the growing number of children engaging in a variety of different screen activities in a dependent; problematic manner. The concept and diagnostic criteria derive from pathological gambling and substance-related addictions and are often based on the amount of time spent engaging in a screen activity; such as playing computer games; and the extent to which this compromises the individual's overall functioning [2].

The disorder manifests a myriad of symptoms; including insomnia; backache; weight gain or loss; eyesight problems; headaches; and poor nutrition as physical symptoms. Anxiety; dishonesty; feelings of guilt; and loneliness are the emotional symptoms. Many of those who suffer from the disorder prefer to isolate themselves from others and are often agitated and suffer from mood swings $[3,4]$. Understanding the neurological features of SDD continues to be bedeviled in the literature using terms such as structural or functional 'alterations'; 'changes'; 'reduced' and 'decreased' to describe observed abnormalities or differences between groups in a cross-sectional study as opposed to resultant changes/causal effects over time. However; many researchers do suspect that SDD leads to neuroadaptation. Brain itself actually changes as a consequence of excessive engagement with the Internet and gaming [3,5]. According to American Academy of Pediatrics' new recommendations for children is media use. Dr. Lynn's methods For children younger than 18 
months; avoid use of screen media other than video chatting [5]. Parents of children 18 to 24 months of age who want to introduce digital media should choose high-quality programming and watch it with their children to help them understand what they're seeing. For children ages 2 to 5 years; limit screen use to 1 hour per day of high-quality programs. Parents should coview media with children to help them understand what they are seeing and apply it to the world around them. For children ages 6 and older; place consistent limits on the time spent using media; and the types of media; and make sure media does not take the place of adequate sleep; physical activity and other behaviors essential to health. Set ground rules early and enforce them by designating media free times together; such as dinner or driving; as well as media free locations at home; such as bedrooms [5].

\section{References}

1. Goh SN, Teh LH, Tay WR (2016) Sociodemographic, home environment and parental influences on total and device-specific screen viewing in children aged 2 years and below: an observational study. BMJ Open 6: 009113.

2. Aric Sigman (2017) Screen Dependency Disorders: a new challenge for child neurology. Journal of the International Child Neurology Association 17: 1-15.

3. Kuss DJ, Griffiths MD (2012) Internet and gaming addiction: A systematic literature review of neuroimaging studies. Brain Sci 2(3): 347-374.

4. Clark L (2014) Disordered gambling: the evolving concept of behavioral addiction. Ann NY Acad Sci 1327: 46-61.

5. Wen T, Hsieh S (2016) Network Based Analysis Reveals Functional Connectivity Related to Internet Addiction Tendency. Front Hum Neurosci 10: 6.

\section{Your next submission with Juniper Publishers} will reach you the below assets

- Quality Editorial service

- Swift Peer Review

- Reprints availability

- E-prints Service

- Manuscript Podcast for convenient understanding

- Global attainment for your research

- Manuscript accessibility in different formats

( Pdf, E-pub, Full Text, Audio)

- Unceasing customer service

Track the below URL for one-step submission https://juniperpublishers.com/online-submission.php 